\title{
Rancang Bangun Aplikasi NULIS: Media Pembelajaran Siswa Disgrafia
}

\author{
Peni Sriwahyu Natasari, Dwi Sunaryono, dan Rully Soelaiman \\ Jurusan Teknik Informatika, Fakultas Teknologi Informasi, Institut Teknologi Sepuluh Nopember (ITS) \\ Jl. Arief Rahman Hakim, Surabaya 60111 Indonesia \\ e-mail:dwi@its-sby.edu, rully@is.its.ac.id, peni.natasari12@mhs.if.its.ac.id
}

\begin{abstract}
Abstrak-Siswa penyandang disgrafia atau kesulitan belajar menulis merupakan salah satu dari 'Learning Disorder'. Pada anak kesulitan belajar menulis, proses menuliskan informasi merupakan hal sangat sulit. Kemampuan motorik anak terganggu dan mengakibatkan kemampuan gerak dalam kehidupan seharihari juga mengalami kesulitan.

Siswa disgrafia dapat disembuhkan dengan melakukan kegiatan menulis secara terus-menerus serta memberikan pelatihan motorik. Salah satu solusi untuk permasalahan ini pada bidang teknologi yaitu pengembangan aplikasi NULIS. Aplikasi NULIS memiliki dua jenis muatan yaitu pada mata pelajaran Bahasa Indonesia dan Matematika yang dapat dipersonalisasikan oleh pendidik terhadap kebutuhan siswa.

Penulis telah melakukan pembelajaran terhadap 5 siswa di Sekolah Aditama Surabaya, dan memperoleh hasil sebesar $\mathbf{6 5 \%}$ parameter kemampuan menulis mengalami peningkatan. Selain itu aplikasi NULIS dapat membantu pembelajaran pada anak dengan keleluasaan pendidik dalam mengubah aktivitas. Pada akhirnya, penggunaan dari perangkat bergerak dengan muatan multimedia yang interaktif dapat meningkatkan minat siswa dalam pembelajaran..
\end{abstract}

Kata Kunci-aplikasi NULIS, Siswa Disgrafia, Media Pembelajaran.

\section{PENDAHULUAN}

$\mathrm{D}_{\mathrm{k}}$ ISGRAFIA merupakan suatu kondisi yang menyebabkan kesulitan pengekspresian tulisan [1]. Penyebab disgrafia disebabkan karena faktor gangguan otak yang berhubungan dengan kemampuan motorik. Disgrafia termasuk salah satu dari learning disorder. Disgrafia dapat pula terjadi bersamaan dengan ketidakmampuan belajar lain. Karakteristik seseorang mengalami disgrafia diantaranya tampak berusaha keras dalam mengekspresikan ide melalui tulisan, tulisan tangan yang tidak teratur pada ukuran huruf, jarak antar huruf maupun jarak antar kata, serta tetap mengalami kesulitan meskipun menyalin contoh huruf atau tulisan. Sebuah survei dari K-5 teachers menuliskan bahwa siswa sekolah dasar menghabiskan $24-58 \%$ waktu belajar di kelas untuk menulis di atas kertas [2]. Hal tersebut menunjukkan bahwa intensitas dari kegiatan menulis cukup tinggi.

Pada bidang teknologi informasi telah dikembangkan beberapa aplikasi yang mempelajari dan diperlukan bagi mereka penyandang disgrafia. Computerized Penmanship Tool merupakan aplikasi yang mengumpulkan dan menganalisa data dari penulisan pada digitizer. Ductus aplikasi untuk menganalisa data saat dilakukan proses menulis, HandSpy aplikasi berbasis web yang melakukan pengolahan secara distributif dan kolaboratif pada proses menulis. The Eye and Pen perangkat untuk merekam gerakan tangan yang sinkron dengan mata saat menulis [3]. Ada beberapa aplikasi mobile pada platform iOS yaitu 'Wet-Dry-Try for Capitals, Numbers \& Lowercase' [4] dan LetterSchool [5] yang membantu anak untuk praktik menulis. Namun dari aplikasi yang sudah ada diatas beberapa memerlukan perangkat yang harganya tidak murah dan berbayar. Beberapa aplikasi lainnya tidak kompatibel pada platform selain iOS.

Aplikasi NULIS mampu memberikan informasi perkembangan anak dengan mendokumentasikan riwayat aktivitas dengan baik serta pendidik dapat membuat rencana pembelajaran yang disesuaikan dengan kemampuan siswa. Tahapan utama penggunaan yaitu persiapan, penggunaan dan evaluasi. Hasil yang diharapkan yaitu pendidik dan orang tua dapat mengetahui perkembangan siswa yang informatif. Hal ini akan mempermudah pendidik serta orang tua untuk mengetahui tingkat kemampuan menulis siswa dan mempermudah dalam penentuan tahap pembelajaran selanjutnya.

\section{TINJAUAN PUSTAKA}

\section{A. Disgrafia}

Kesulitan menulis sering disebut sebagai disgrafia. Kesulitan menulis tersebut dapat terlihat pada performa yang tidak memadai dibandingkan dengan tulisan tangan anak-anak dengan tingkat kecerdasannya rata-rata dan dibandingkan dengan anak yang belum diidentifikasi memiliki masalah neurogolis atau perseptual-motor yang jelas [6]. Pada penelitian sebelumnya, prevalensi atau nilai kemungkinan yang dapat terjadi pada sekelompok anak untuk masalah tulisan tangan pada anak-anak usia sekolah diperkirakan bervariasi antara 5 sampai 33\% [7] [8] [9] [10] [11]. Para ahli meyakini bahwa salah satu langkah ataupun kedua langkah proses penulisan berikut tidak berjalan sempurna [1]:

1. Mengorganisir informasi yang disimpan dalam memori

2. Merepresentasikan kata pada kertas dengan tangan ataupun mengetik kata tersebut.

Disgrafia dapat dialami oleh anak-anak, remaja, dan dewasa. Gejala disgrafia umumnya muncul ketika anak mulai belajar menulis. Seseorang yang menderita disgrafia dapat pula memiliki kemampuan bicara yang baik. Sehingga terkadang orang tua dan pendidik tidak menyadari bahwa anaknya memiliki kesulitan dalam mengekspresikan tulisan serta menganggap anak tidak mau belajar menulis. 


\section{B. Tahap Mengatasi Disgrafia}

Orang tua dapat melakukan tindakan-tindakan pada anak yang mengalami disgrafia. Gejala anak yang mengalami gangguan belajar menulis dapat dilakukan langkah-langkah penanggulangan yang bias dilakukan [12].

1) Pahami keadaan anak

Tidak membandingkan anak dengan gangguan belajar menulis dengan anak lain yang normal.

2) Menyajikan tulisan cetak

Memberi kesempatan pada anak untuk belajar menuangkan ide-idenya dengan menggunakan media komputer.

3) Bangun rasa percaya diri

Memberikan pujiaan pada saat yang tepat dan wajar setiap usaha yang dilakukan anak.

4) Latih anak terus menulis

Memberikan tugas-tugas menarik, seperti menulis surat untuk teman, orang tua, menulis pada selembar kartu pos dan sejenisnya.

\section{Teknologi Terkait yang Pernah Dikembangkan}

ComPET dikembangkan dengan bantuan perangkat lunak Matlab yang digunakan untuk mengelola ransangan dan mengumpulkan serta menganalisa data. Perangkat lunak ini memiliki dua bagian independen. (1) Perangkat lunak untuk pengumpulan data dan (2) Perangkat lunak untuk analisis data. Data yang dianalisis berupa spasial dan temporal dari proses menulis, kecepatan dan percepatan dari penulisan pada digitizer. Data yang dikumpulkan akan dikirimkan ke laboratorium melalui internet untuk dianalisis. Hasil dari analisis akan dikembalikan dalam waktu seminggu [13].

HandSpy merupakan aplikasi berbasis website untuk mengelola secara distributif dan kolaboratif pada proses kognitif menulis. Penyimpanan data disimpan dalam bentuk file XML. Pada layer presentasi menggunakan Javascript framework. SmartClient Javascript framework dapat terhubung pada sumber data dalam format XML yang disesuaikan dengan data HandSpy [14].

D. Analisis Tulisan Tangan Anak-anak pada Perangkat Bergerak Layar Sentuh

Menulis pada media kertas dan papan tulis merupakan hal yang umum, namun dengan ketersediaan teknologi baru yaitu perangkat bergerak layar sentuh memberikan potensi baru untuk memberikan inovasi belajar mengajar.

Elba del Carmen Valderrama Bahamóndez bersama rekan melakukan analisis mengenai tulisan tangan anak pada perangkat bergerak layar sentuh. Penelitian ini membandingkan penulisan menggunakan pena dan kertas dengan penulisan pada perangkat bergerak layar sentuh dan menghasilkan performa tulisan dan tingkat keterbacaan lebih baik pada penulisan menggunakan pena di atas kertas. Selain itu dilakukan percobaan pula penulisan dengan bantuan stylus dan hasilnya performa penulisan anak lebih baik jika menggunakan stylus dibandingkan dengan jari pada penulisan pada perangkat bergerak layar sentuh [15].

Teknologi layar sentuh pada perangkat bergerak memberikan kesempatan menarik untuk menciptakan tugas belajar umum [16, 17]. Melihat kegunaan tersebut kelebihan dari penggunaan perangkat bergerak layar sentuh yaitu murah, memerlukan sedikit infrastruktur, dan menawarkan kesempatan untuk mendukung tulisan tangan menggunakan jari maupun stylus [15].

\section{ANALISIS DAN PERANCANGAN}

\section{A. Domain Permasalahan}

Siswa yang membutuhkan pendidikan khusus memiliki keterbatasan untuk melakukan beberapa hal sesuai kesulitan yang dialami, sehingga memerlukan tindakan lebih untuk meningkatkan kemampuan siswa. Tindakan tersebut dapat diusahakan orang tua, pendidik, maupun dari siswa sendiri. Bidang teknologi juga mampu memberikan jalan baru dalam memberikan inovasi untuk pembelajaran siswa dengan kebutuhan pendidikan khusus. Teknologi mampu memberikan keuntungan agar siswa terlibat aktif secara mandiri untuk meningkatkan kemampuanya.

Penggunaan teknologi seperti komputer dan perangkat bergerak dalam kegiatan belajar pada siswa kerap kali menunjukkan peningkatan perhatian dan kinerja dari siswa. Pembelajaran dengan multimedia tersebut membuat anak lebih fokus terhadap kegiatan yang mereka lakukan lebih dari biasanya serta membantu dalam menjaga keberlanjutan pembelajaran yang dilakukan pendidik maupun orang tua.

Pendidik dari siswa dengan pendidikan khusus pada kesulitan belajar menulis memiliki keterbatasan dan kesulitan dalam melakukan pengajaran. Beberapa hal tersebut yaitu penyiapan aktivitas menulis seperti cetakan tulisan dengan bantuan garis putus-putus, menyiapkan alat peraga untuk presentasi gambar yang sesuai dengan tulisan dan kesulitan dalam penyesuaian aktivitas secara cepat terhadap kebutuhan siswa karena tingkat kemmpuan siswa yang berbeda-beda dalam satu kelas.

Aplikasi yang dapat disesuaikan dengan kebutuhan siswa dibutuhkan untuk memberikan keleluasaan bagi pendidik agar kegiatan belajar lebih fleksibel. Perangkat bergerak menjadi pendukung untuk memberikan kebebasan berganti lokasi bagi siswa untuk belajar seperti dari sekolah ke rumah dan kebebasan mengerjakan aktivitas tanpa dibatasi waktu dan tempat.

\section{B. Analisis Pendekatan Keterbatasan Anak Disgrafia Melalui Perangkat Bergerak}

Pendekatan melalui perangkat bergerak untuk mengatasi beberapa keterbatasan anak penyandang disgrafia dapat dilakukan dengan mempertimbangkan analisis berikut:

1) Memberikan pembelajaran interaktif yang meningkatkan ketertarikan anak dalam belajar sebagai solusi untuk masalah anak menghindari kegiatan menulis

2) Penggunaan perangkat bergerak yang tidak dibatasi waktu dan tempat membantu menjaga suasana hati anak serta menjaga keberlanjutan belajar sebagai salah satu inovasi pembelajaran yang berkelanjutan

3) Layar sentuh pada perangkat lunak menjadikan anak bebas menulis dengan aktivitas menggambar pada aplikasi, sebagai solusi dari terbatasnya media jika menggunakan kertas 
4) Perangkat bergerak yang sifatnya keras tidak memerlukan alas sehingga lebih mudah bagi anak untuk menulis meskipun dengan posisi sulit jika menulis menggunakan kertas (posisi duduk bersila)

5) Perangkat bergerak memberikan gambar yang nyata sehingga anak mudah memahami apa yang dituliskan, sebagai solusi dari kesalahan representasi gambar.

\section{Analisis Pendekatan Anak Disgrafia Melalui Aplikasi}

Berdasarkan cara mengatasi disgrafia dan kemungkinan yang diberikan perangkat bergerak layar sentuh untuk menulis maka dapat dilakukan pendekatan berikut melalui aplikasi yang dikembangkan:

1) Dapat melakukan perubahan muatan aktivitas secara cepat.

2) Dapat menggunakan aktivitas yang sama secara berulangulang.

3) Kebebasan memilih gambar saat merancang rangkaian aktivitas pada muatan aktivitas tertentu.

4) Membuat mudah digunakan.

\section{Deskripsi Umum}

Berdasarkan permasalahan yang diangkat pada domain permasalahan, maka salah satu solusi untuk siswa penyandang disgrafia yaitu aplikasi NULIS. Aplikasi NULIS merupakan aplikasi yang dapat berjalan diberbagai platform perangkat bergerak yaitu Android, Windows Phone, dan iOS dan diperuntukkan untuk pendidik dan siswa dengan beberapa kemampuan seperti yang dipresentasikan pada Gambar 2 . Gambar 1 menjelaskan arsitektur sistem yang secara detail dijelaskan bersama kebutuhan fungsional sistem sebagai berikut:

1) Modul profil siswa: Pendidik dapat mengelola profil siswa yaitu menambahkan data siswa baru, mengubah serta menghapus data siswa;

2) Modul rancangan aktivitas: Pendidik dapat mengelola rancangan aktivitas siswa dengan menambahkan, mengurangi serta mengkonfigurasi aktivitas yang akan dikerjakan oleh siswa;

3) Modul aktivitas pembelajaran: Siswa mengerjakan aktivitas yang telah dirancang oleh pendidik;

4) Modul evaluasi: Pendidik dapat mengetahui hasil evaluasi siswa berdasarkan aktivitas-aktivitas yang telah dikerjakan oleh siswa.

Selain kebutuhan fungsional analisis mengenai muatan aktivitas penting dilakukan. Muatan aktivitas merupakan muatan yang disediakan sistem. Penentuan muatan aktivitas didasarkan pada Kurikulum Sekolah Luar Biasa kelas 1 tingkat sekolah dasar [18] dengan menganalisis dimensi pendidik. Pada Gambar 3 ditunjukkan bahwa dimensi pendidik terdiri dari dua dimensi, yaitu dimensi pembelajaran yang didalamnya terdapat kurikulum pendidikan dan dimensi siswa yang didalamnya terdapat pengidentifikasian karakteristik siswa. Pada dimensi pembelajaran, pendidik menentukan tingkat aktivitas dengan cara menganalisis kurikulum dan mengumpulkan berbagai variasi pembelajaran. Sedangkan untuk dimensi siswa, pendidik harus menganalisis potensi siswa. Kedua dimensi tersebut menentukan cara pembelajaran dan penilaian yang akan diberikan pendidik kepada siswa.
Aplikasi NULIS menyediakan template aktivitas yang dapat digunakan pendidik untuk merancang pembelajaran yang berisi berbagai aktivitas dalam suatu rangkaian aktivitas. Aktivitas yang akan ditambahkan akan disertai demo aktivitas, sehingga pendidik mempunyai gambaran aktivitas yang akan dikerjakan oleh siswa. Setelah ditambahkan ke rangkaian aktivitas siswa, pendidik dapat mengatur tingkat kesulitan dari beberapa aktivitas, menentukan huruf, kata, dan kalimat serta memilih gambar yang sesuai dengan kata. Pendidik juga mampu menentukan ukuran tulisan pada beberapa aktivitas. Jika rangkaian aktivitas telah sesuai maka siswa dapat mengerjakan aktivitas. Pada akhir pengerjaan pendidik dapat melakukan penilaian. Penilaian yang diberikan bersifat subjektif dari pendidik. Nilai yang tersimpan akan menjadi acuan dari informasi perkembangan siswa yang ditampilkan oleh sistem. Penjelasan secara terurut proses penggunaan aplikasi dapat dilihat pada Gambar 4. Beberapa tampilan dapat dilihat pada Gambar 5 dan Gambar 6.

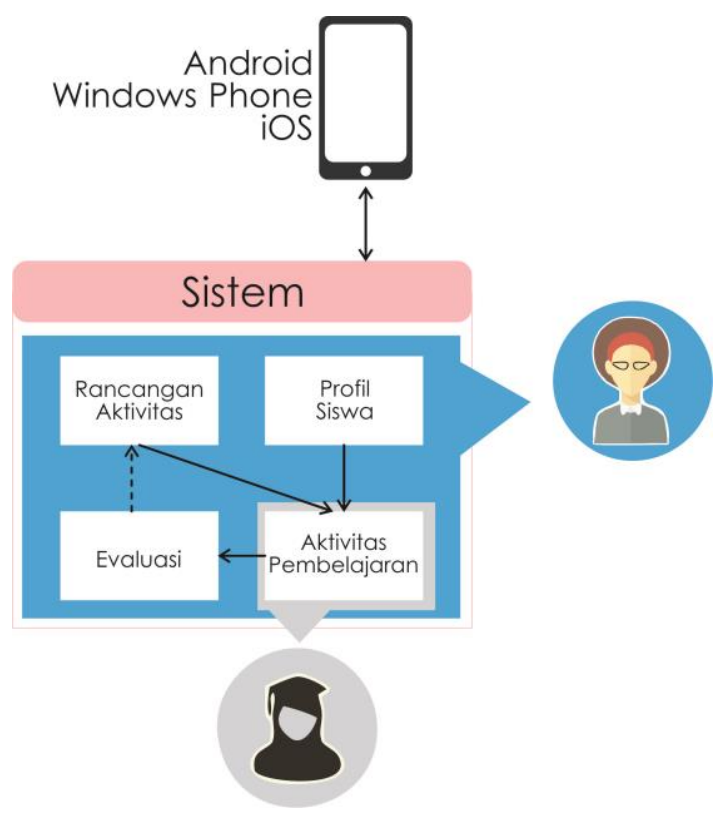

Gambar 1. Arsitektur Sistem

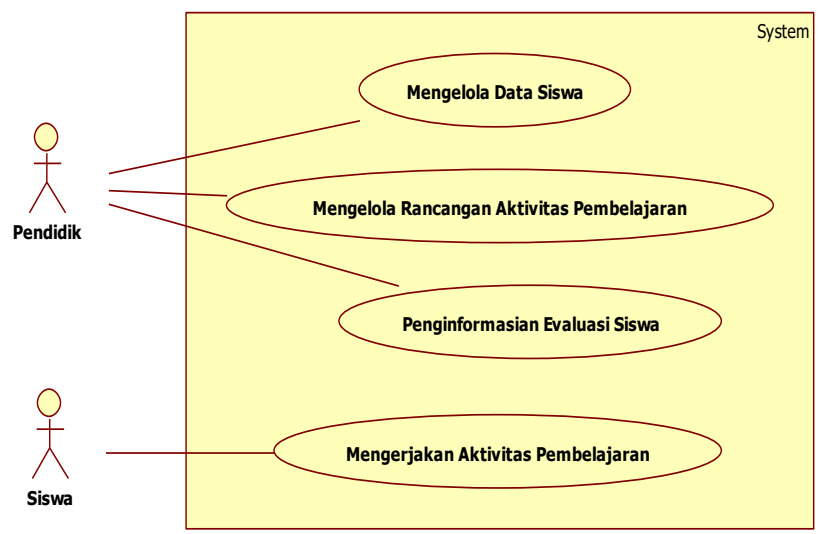

Gambar 2. Diagram Kasus Penggunaan 


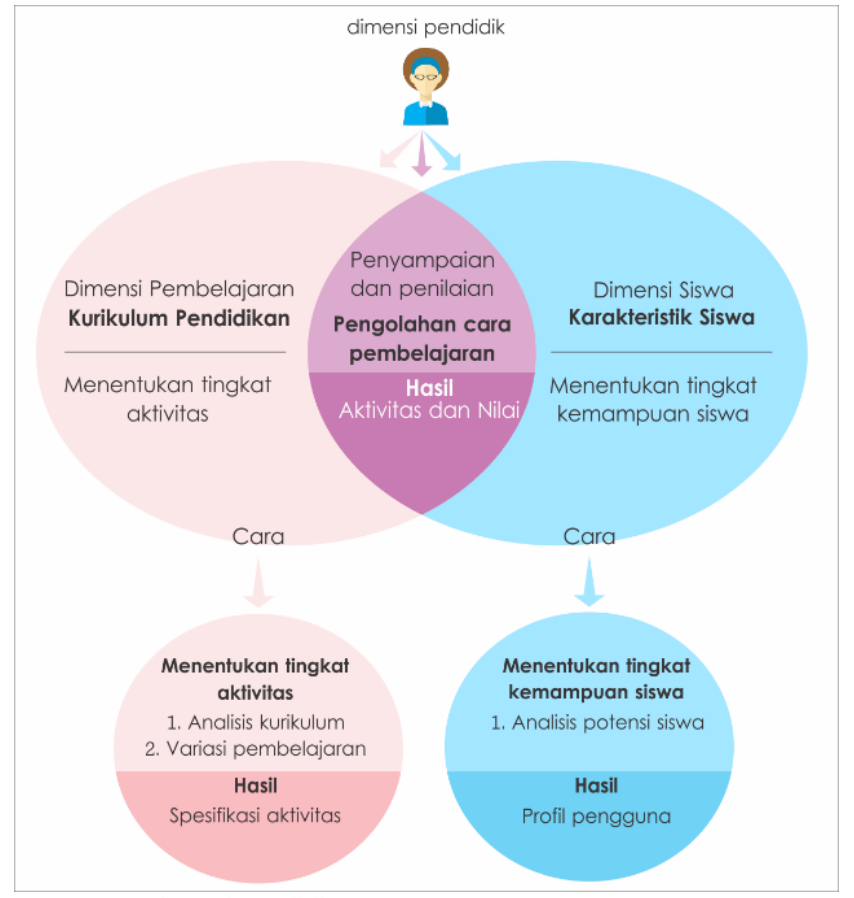

Gambar 3. Dimensi Pendidik

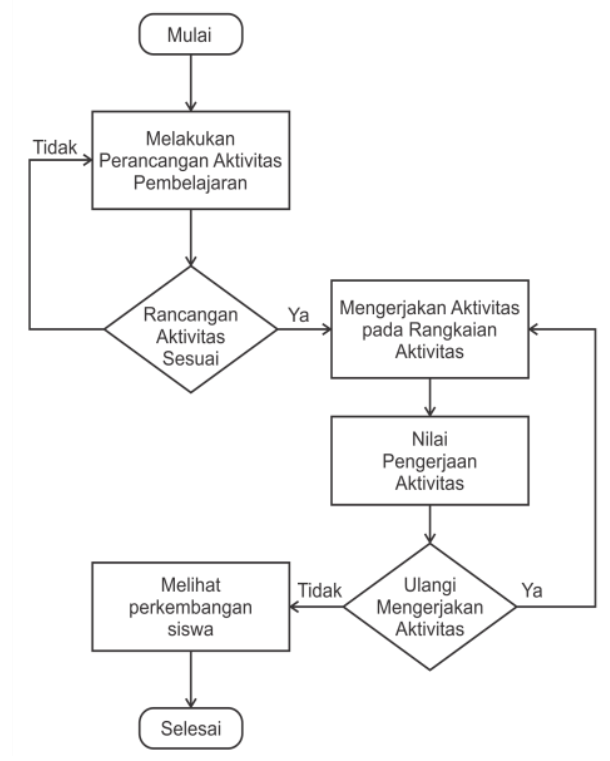

Gambar 4. Diagram Alir Aplikasi NULIS

\section{E. Pengguna Sistem}

Pengguna dari sistem terdiri dari pendidik (guru atau orang tua) dan siswa. Pendidik memiliki hak akses ke sistem dengan memiliki akun terlebih dahulu untuk dapat mengelola rancangan aktivitas, melakukan penilaian, dan mengetahui perkembangan kemampuan siswa. Pengguna kedua yaitu siswa dapat melakukan pengerjaan aktivitas yang telah dirancang oleh pendidik.
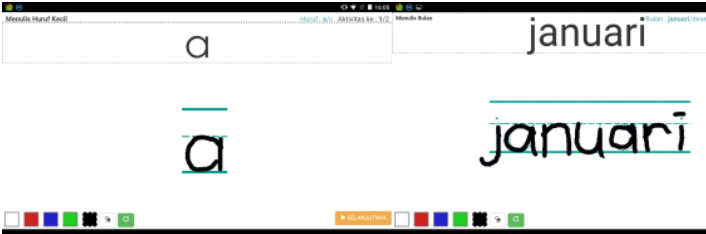

Gambar 5. Halaman Pengerjaan Aktivitas

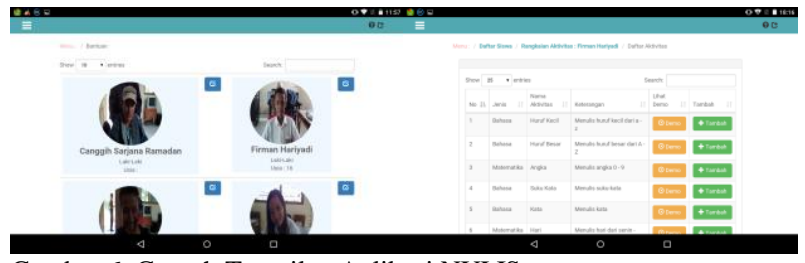

Gambar 6. Contoh Tampilan Aplikasi NULIS

\section{PENGUJIAN}

\section{A. Pengujian Performa Kecepatan}

Pengujian performa kecepatan membuka halaman pada setiap fungsionalitas dilakukan dengan menggunakan Network Evaluating Tools yang disediakan oleh Google Chrome. Berdasarkan pengujian ini rata-rata waktu reaksi dari halaman sebesar 0.28 detik.

\section{B. Pengujian Statistik}

Pengujian statistik ditujukan untuk membuktikan bahwa aplikasi NULIS memiliki dampak yang positif terhadap perkembangan kemampuan menulis siswa. Pengujian ini membutuhkan data kemampuan siswa sebelum aplikasi diterapkan dalam pembelajaran (pretest) dan data kemampuan setelah penggunaan aplikasi (pretest). Hasil kuisioner pada siswa dicantumkan pada Tabel 1.

Tabel 1.

Hasil Uji Coba Kuisioner pada Siswa

\begin{tabular}{cccccc}
\hline \hline No & Nama & $\begin{array}{c}\text { Jumlah } \\
\text { Aktivitas }\end{array}$ & Naik & Tetap & Turun \\
\hline 1 & Annisya F & 33 & 29 & 4 & 0 \\
2 & Canggih S & 33 & 29 & 3 & 1 \\
3 & Firman H & 26 & 17 & 6 & 3 \\
4 & Okta Wira & 31 & 26 & 5 & 0 \\
5 & Renny P & 26 & 18 & 6 & 2 \\
\hline \hline
\end{tabular}

Terdapat kemampuan yang mengalami kenaikan dan penurunan. Kemampuan yang mengalami penurunan cenderung merupakan aktivitas yang dilakukan pada percobaan pertama maupun kedua di hari-hari pengujian. Percobaan pertama maupun kedua merupakan waktu ketika siswa melakukan adaptasi terhadap penggunaan stylus.

Berdasarkan Tabel 1, siswa yang bernama Annisya F 87.9\% kemampuan mengalami kenaikan dan sebesar $12.1 \%$ kemampuan tidak mengalami perubahan. Pada Canggih S 87.9\% kemampuan mengalami peningkatan dan 9.1\% kemampuan tetap, serta 3\% kemampuan menurun. Pada Firman H 65.4\% kemampuan mengalami kenaikan, 23,1\% tidak mengalami perubahan, dan $11.5 \%$ kemampuan mengalami penurunan. Pada Okta Wira 83.8\% kemampuan mengalami kenaikan dan $16.2 \%$ kemampuan tetap. Pada Renny P $69.2 \%$ mengalami peningkatan, $23.1 \%$ kemampuan tetap, dan $7.7 \%$ kemampuan mengalami penurunan. Berdasarkan data yang didapat maka lebih dari $65 \%$ parameter kemampuan anak meningkat.

Pengujian statistik berikutnya melibatkan pendidik. Terdapat tiga pendidik yang mengisi kuisioner dengan pilihan dari 1 hingga 4, yaitu pilihan 1 'sangat setuju' hingga pilihan 4 'sangat kurang setuju'. Dari 32 pernyataan dihasilkan 12 pernyataan bernilai 1 yaitu 'sangat setuju' dan 20 penyataan 
bernilai 'setuju'. Berdasarkan hasil yang diberikan maka secara keseluruhan aplikasi telah sesuai dengan kebutuhan pendidik dan kurikulum pendidikan serta mampu membantu pendidik dalam mengajar di kelas.

\section{KESIMPULAN}

Dari hasil pengamatan selama proses perancangan hasil uji coba yang telah dilakukan terhadap sistem yang dikembangkan, diambil kesimpulan sebagai berikut:

1) Berdasarkan hasil pengujian dengan penggunaan aplikasi pada 5 siswa, aplikasi NULIS dapat meningkatkan $65 \%$ parameter kemampuan menulis pada anak penyandang disgrafia;

2) Berdasarkan hasil kuisioner dari 3 pendidik sebagai responden dapat disimpulkan bahwa aplikasi NULIS dapat membantu pendidik untuk mengajar anak digrafia dengan keleluasaan dapat merancang aktivitas sendiri.

Secara keseluruhan aplikasi NULIS dapat memberikan inovasi pembelajaran di kelas. Kemampuan dalam memberikan informasi mengenai perkembangan siswa kepada pendidik merupakan salah satu hal penting. Penggunaan aplikasi yang tidak dibatasi oleh waktu dan tempat juga memberikan keuntungan bagi pendidik dan siswa. Selain kelebihan tersebut terdapat beberapa kekurangan yang belum didukung oleh aplikasi yaitu fitur untuk mempertimbangkan tekanan saat menulis.

Pengembangan yang dapat dilakukan berikutnya yaitu dengan menambah variasi jenis muatan aktivitas belajar, menambah fitur penilaian secara online serta memanfaatkan 3D touch pada perangkat bergerak yang mendukung sebagai penanganan fitur tekanan saat menulis.

\section{DAFTAR PUSTAKA}

[1] "Understanding Dysgraphia in Children | Written Expression Issues Understood," UNDERSTOOD.ORG USA LLC, 2014-2016. [Online]. Available: $\quad$ https://www.understood.org/en/learning-attentionissues/child-learning-disabilities/dysgraphia/understanding-dysgraphia. [Accessed 15 September 2015].

[2] hwtears.com, "Handwriting Without Tears | K5," Research Review, pp. 1-10, 2015.

[3] D. Alamargot, D. Chesnet, C. Dansac and C. Ros, "Eye and Pen: A new device for studying reading during writing," Behavior Research Methods, vol. 38, no. 2, pp. 287-299, 2006.

[4] "Handwriting Without Tears: Wet-Dry-Try for Capitals, Numbers \& Lowercase on the App Store," Apple Inc, 2016. [Online]. Available: https://itunes.apple.com/en/app/handwriting-withouttears/id548753732? $\mathrm{mt}=8$. [Accessed July 2016].

[5] "LetterSchool - learn to write letters and numbers," Apple Inc, 2016. [Online]. Available: https://itunes.apple.com/us/app/letterschool-learnto-write/id435476174? $\mathrm{mt}=8$. [Accessed July 2016].

[6] S. Rosenblum, P. L. Weiss and P. Shula, "PRODUCT AND PROCESS EVALUATION OF HANDWRITING DIFFICULTIES: A REVIEW," Educational Psychology Review, vol. 15, no. 1, pp. 41-81, 2003.

[7] A. Overvelde and W. Hulstijn, "Handwriting development in grade 2 and grade 3 primary school children with normal, at risk, or dysgraphic characteristics," Research in Developmental Disabilities, vol. 32, pp. 540-548, 2010.

[8] L. Hamstra-Bletz and A. W. Blote, "A Longitudinal Study on Dysgraphia Handwriting in Primary School," Journal of Learning Disabilities, vol. 26, no. 10, pp. 689-699, 1993.
[9] R. Karlsdottir and T. Stefansson, "PROBLEMS IN DEVELOPING FUNCTIONAL HANDWRITING," Perceptual and Motor Skills, vol. 94, pp. 623-662, 2002.

[10] N. Rubin and S. E. Handerson, "Two Sides of the Same Coin: Variations in Teaching Methods and Failure to Learn to Write," Special Education: Forward Trends, vol. 9, no. 4, pp. 17-24, 1982.

[11] B. Smits-Engelsman, A. Niemeijer and G. Van Galen, "Fine motor deficiencies in children diagnosed as DCD based on poor grapho-motor ability," Human Movement Science, vol. 20, pp. 161-182, 2001.

[12] A. M. M, Panduan Lengkap Orangtua dan Guru untuk Anak dengan Disgrafia (Kesulitan Menulis)., vol. 27, Yogyakarta: Javalitera, pp. 200214.

[13] S. Rosenblum, A. Y. Dvorkin and P. L. Weiss, "Automatic segmentation as a tool for examining the handwriting process of children with dysgraphic and proficient handwriting," Human Movement Science, vol. 25, pp. 608-621, 2006.

[14] C. Monteiro and J. P. Leal, "HandSpy - a system to manage experiments on cognitive processes in writing," In Symposium on language, Applications and Technologies, SLATE, pp. 123-132, 2012.

[15] V. B. Elba del Carmen, T. Kubitza, N. Henze and A. Schmidt, "Analysis of Children's Handwriting on Touchscreen Phones," 15th International ACM Conference on Human-Computer Interaction With Mobile Devices and Services (MobileHCI '13), 2013.

[16] Valderrama B., E., Winkler, C., and Schmidt, A. Utilizing multimedia capabilities of mobile phones to support teaching in schools in rural panama. In Proc. CHI, 2011.

[17] $\mathrm{Ng}, \mathrm{W}$. and Nicholas, H. Capturing thinking with handheld computers. In Proc. Mobile Learning, 2009

Badan Standar Nasional Pendidikan, Standar Isi untuk Satuan Pendidikan Dasar dan Menengah Standar Kompetensi dan Kompetensi Dasar SDLB, Jakarta: BSNP, 2006.

\section{LAMPIRAN}

Tabel 2.

Hasil Kuisioner pada Pendidik

\begin{tabular}{|c|c|c|}
\hline No & Pernyataan & Modus \\
\hline & Perencanaan pembelajaran menggunakan Aplikasi & \\
\hline 1 & $\begin{array}{l}\text { NULIS pada perangkat bergerak lebih dinamis (mudah } \\
\text { menyesuaikan) daripada pembelajaran menggunakan } \\
\text { kertas. }\end{array}$ & 2 \\
\hline 2 & $\begin{array}{l}\text { Fitur 'perancangan pembelajaran' yang dapat diubah } \\
\text { oleh pendidik mempermudah dalam melakukan } \\
\text { kegiatan belajar mengajar }\end{array}$ & 2 \\
\hline 3 & $\begin{array}{l}\text { Fitur 'melihat perkembangan siswa' dapat membantu } \\
\text { pendidik mengetahui tingkat kemampuan siswa dalam } \\
\text { menulis. }\end{array}$ & 2 \\
\hline 4 & $\begin{array}{l}\text { Aplikasi dapat menjalankan aktivitas sesuai dengan } \\
\text { rencana pembelajaran yang dibuat. }\end{array}$ & 2 \\
\hline 5 & $\begin{array}{l}\text { Fitur 'mengubah aktivitas' sangat membantu dalam } \\
\text { menentukan perancangan pembelajaran. }\end{array}$ & 2 \\
\hline 6 & Aplikasi mudah digunakan. & 1 \\
\hline 7 & Tampilan aplikasi mudah dipahami & 2 \\
\hline 8 & $\begin{array}{l}\text { Pembelajaran dengan aplikasi NULIS membuat anak } \\
\text { giat belajar dan semakin percaya diri }\end{array}$ & 1 \\
\hline 9 & $\begin{array}{l}\text { Pembelajaran dengan aplikasi NULIS membantu } \\
\text { pendidik untuk mengajar. }\end{array}$ & 2 \\
\hline 10 & $\begin{array}{l}\text { Aktivitas yang ada pada aplikasi NULIS sudah sesuai } \\
\text { dengan kurikulum yang diajarkan }\end{array}$ & 2 \\
\hline \multirow{11}{*}{11} & \multicolumn{2}{|c|}{$\begin{array}{l}\text { Daftar muatan aktivitas yang ada pada aplikasi dibutuhkan dalam } \\
\text { pembelajaran. }\end{array}$} \\
\hline & Menulis huruf kecil & 2 \\
\hline & Menulis huruf besar & 1 \\
\hline & Menulis kata & 1 \\
\hline & Menulis teka-teki & 2 \\
\hline & Menulis kalimat & 1 \\
\hline & Menulis angka & 1 \\
\hline & Menulis hari & 2 \\
\hline & Menulis bulan & 2 \\
\hline & Menulis jam & 2 \\
\hline & Menebali garis dan bentuk & 2 \\
\hline
\end{tabular}


Daftar muatan aktivitas yang ada pada aplikasi telah berjalan

dengan baik.

Menulis huruf kecil

Menulis huruf besar

Menulis suku kata

Menulis kata

Menulis teka-teki

Menulis kalimat

Menulis angka

Menulis hari

Menulis bulan

Menulis jam

Menebali garis dan bentuk

\begin{tabular}{l}
1 \\
1 \\
2 \\
1 \\
2 \\
1 \\
1 \\
2 \\
2 \\
2 \\
2 \\
\hline
\end{tabular}

